\title{
Proliferative fasciitis: a culprit of a huge infected antrochoanal polyp in a 7-year-old girl
}

\author{
Proliferacyjne zapalenie powięzi jako przyczyna ogromnego, zakażonego polipa choanalnego \\ u 7-letniej dziewczynki
}

\author{
1 Department of Otorhinolaryngology - Head and Neck Surgery, Hospital Ampang, Selangor, Malaysia \\ ${ }^{2}$ Department of Otorhinolaryngology - Head and Neck Surgery, Universiti Malaya, Kuala Lumpur, Malaysia \\ ${ }^{3}$ Department of Otorhinolaryngology - Head and Neck Surgery, Hospital Tengku Ampuan Rahimah, Klang, Malaysia \\ ${ }^{4}$ Department of Otorhinolaryngology - Head and Neck Surgery, National University of Malaysia, Kuala Lumpur, Malaysia \\ Correspondence: Dr Reuben Abraham Thomas, Department of Otorhinolaryngology, Head and Neck Surgery, Hospital Ampang, Jalan Mewah Utara, Pandan Indah, 68000 Ampang, Selangor, Malaysia, \\ tel.: +6017 7721985, e-mail: reubencrm@gmail.com
}

Abstract Antrochoanal polyps are occasionally encountered in an ear, nose and throat practice and most of them present with progressive unilateral nasal blockage. This paper depicts a pediatric patient's peculiar presentation of an infected antrochoanal polyp along with obstructive symptoms as the stalk of the antrochoanal polyp which favours proliferative fasciitis could be a possible cause of an acute manifestation of the disease. The stalk, which was adherent to the medial wall of the maxillary sinus and anterior portion of the polyp was removed via intranasal endoscopic approach. Postoperatively, the patient was discharged well and after two years of follow-up, there were no signs of recurrence.

Keywords: proliferative fasciitis, antrochoanal polyp, paediatric rhinology, pseudosarcomatous lesion

Streszczenie

Polipy choanalne są sporadycznie spotykane w praktyce laryngologicznej i większość z nich przebiega z postępującą jednostronną niedrożnością jamy nosowej. W pracy przedstawiono przypadek dziecka ze szczególną postacią zakażonego polipa choanalnego, u którego wystąpiły objawy blokady albo niedrożności przewodu nosowego. Ostry przebieg schorzenia mógł być spowodowany obecnością szypuły polipa, która sprzyja proliferacyjnemu zapaleniu powięzi. Szypułę, która przylegała do przyśrodkowej ściany zatoki szczękowej i przedniej części polipa, usunięto z donosowego dostępu endoskopowego. Po zabiegu pacjentkę wypisano do domu. W badaniu kontrolnym przeprowadzonym po dwóch latach nie stwierdzono oznak nawrotu.

Słowa kluczowe: proliferacyjne zapalenie powięzi, polip choanalny, rynologia dziecięca, zmiana rzekomomięsakowa 


\section{INTRODUCTION}

A ntrochoanal polyp (ACP) is a benign, soft tissue mass that arises from inflamed and oedematous mucosa of the maxillary antrum, which herniates through the ostium and extends along the nasal cavity to the choana. Proliferative fasciitis (PF) is a benign lesion with histologic and clinical features overlapping with those of malignant soft tissue tumours. Its occurrence in children is considered very rare. We would like to report this case to highlight the possible importance of adopting PF as one of the causes of a sprouting ACP in a paediatric patient who may present with acute nasal obstruction along with dyspnoea and odynophagia.

\section{CASE REPORT}

A 7-year-old girl presented to the emergency department with shortness of breath and odynophagia with a history of mouth breathing for 2 weeks, however, she denied any prolonged history of nasal blockage or fever. She had no history of allergies or comorbidities. An oral examination revealed a slough-filled mass protruding down from nasopharynx and abutting the soft palate (Fig. 1). A computed tomography (CT) scan showed a large minimally enhancing mass in the nasopharynx, extending anteriorly into both nasal cavities with obliteration of the posterior nasal space, extending inferiorly into oropharynx with the mass abutting the soft palate. There was mucosal thickening seen within both maxillary, sphenoid and ethmoid sinuses.

Examination under general anesthesia revealed a polypoid mass arising from the left maxillary antrum. A clinical diagnosis of ACP was made and an endoscopic left middle meatal antrostomy was performed. The stalk, which was

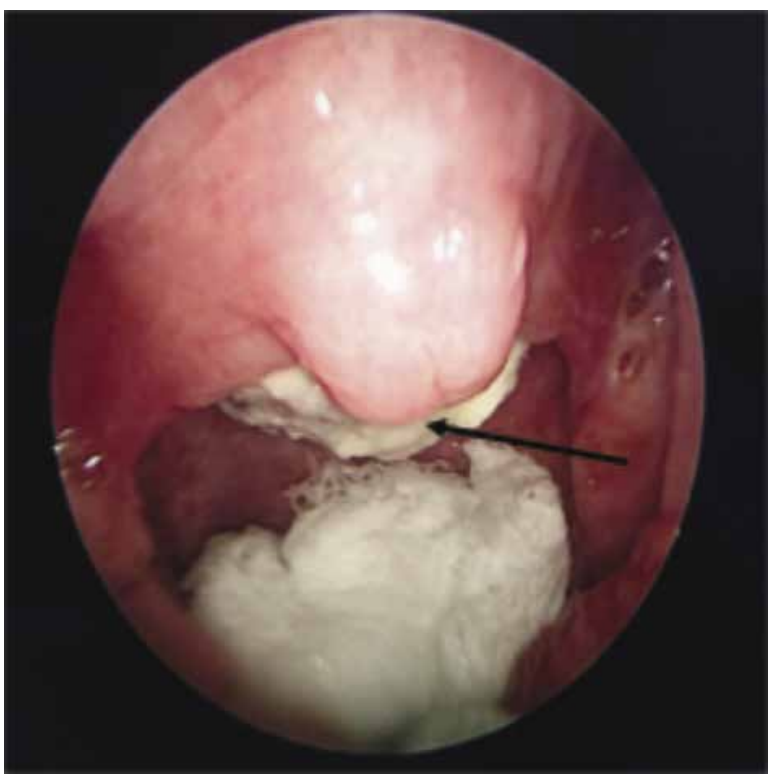

Fig. 1. Endoscopic intraoperative view of the oropharynx showing a nasopharyngeal mass with surrounding slough (arrow) abutting the soft palate inferiorly adherent to the medial wall of the maxillary sinus (Fig. 2) and anterior portion of the polyp was removed via intranasal endoscopic approach and the entire mass (measuring $55 \times 40 \times 30 \mathrm{~mm}$ ) was delivered perorally (Fig. 3). Histopathological examination reported ACP with the stalk consistent with proliferative fasciitis. No atypical mitoses were found.

The patient was discharged well on the second day postoperatively and after two years of follow-up, there were no signs of recurrence.

\section{DISCUSSION}

$\mathrm{ACP}$ is an infrequent benign neoplasm that is more common in males than females and which is more prevalent in children and young adults, though it can manifest at any age $^{(1)}$. ACP tends to be unilateral, but there are few reported cases of bilateral $\mathrm{ACPs}^{(2)}$. PF is a self-limiting, benign, reactive fibroblastic proliferation considered as a pseudosarcomatous lesion because of its microscopic features

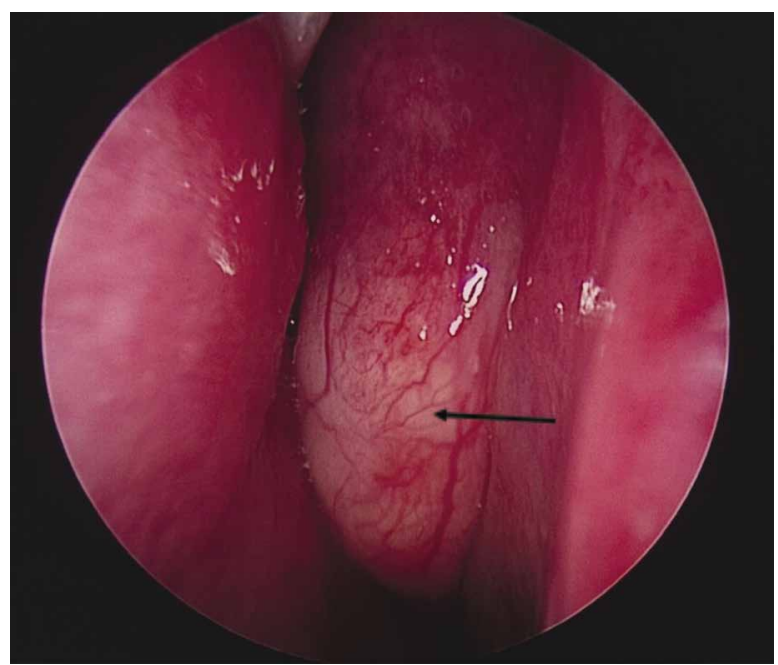

Fig. 2. Intraoperative nasoendoscopic view of the left nasal cavity showing a polypoidal mass arising from the left middle meatus (arrow)

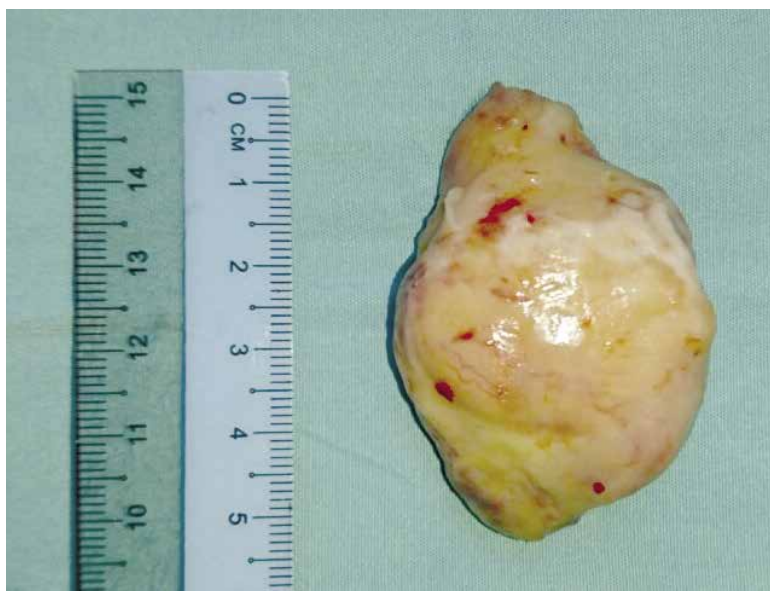

Fig. 3. Polypoidal mass with a stalk 
overlapping with those of malignant soft tissue tumours ${ }^{(3-5)}$. These features were pointed out by Meis and Enzinger ${ }^{(3)}$ who studied the slides of 11 archived cases of paediatric PF and myositis, seven of which were histologically diagnosed previously as "sarcomatous lesions" or rhabdomyosarcomas and were treated aggressively.

There are various pathogenic mechanisms proposed to underly the development of ACP, including chronic inflammatory process and allergy, but the aetiology of ACP still remains unclear ${ }^{(6)}$. Our patient had no clear history of allergy to suggest that as the cause of ACP, but the stalk of the ACP, which favours PF could be a possible cause.

ACP typically consists of two main components; the cystic antral part and another solid part. ACP was originally described to arise from the lateral wall of maxillary antrum, but choanal polyps may arise from the posterior antrum, superior antrum, sphenoid and ethmoid sinuses, soft and hard palates, and the posterior aspect of the nasal septum ${ }^{(7)}$. $\mathrm{PF}$ is considered to be a repair reaction in soft tissue, where minor traumas and inflammation are frequent ${ }^{(5)}$. However, only rarely some type of injury is reported to precede the resulting proliferation, raising the possibility that other causes may play a role in its development ${ }^{(4)}$. Among the reviewed paediatric clinical data, there were only 20 cases of PF reported till date and out of those that were reported, only 2 cases were from the head and neck region (orbit, retroauricular). From our literature search, there has not been any other case which arises from the maxillary sinus, as for our case and of those that were reported, there was no evidence or signs of trauma prior to presentation ${ }^{(3)}$.

Patients with ACP most commonly present with unilateral nasal blockage. However, they may present with epistaxis, rhinorrhoea, sneezing, anosmia, bilateral nasal obstruction, facial pain, snoring, headache, dysphagia, halitosis, dysphonia, dyspnoea ${ }^{(8)}$. In our patient, the ACP had reached a huge size and was infected before presentation. Therefore, the presentation was atypical with a short duration of symptoms, which included sore throat, odynophagia and dyspnoea due to the inflammation and obstruction from the mass.

Endoscopic examination and CT scan are two important tools to diagnose ACP. ACP can be identified on a CT image as a hypoattenuation mass arising from the opaque maxillary sinus, extending through the middle meatus into the nasal cavity between the middle turbinate and the lateral wall of the nasal cavity ${ }^{(9)}$.

The main treatment modality for ACP and PF is complete surgical removal of the polyp and its origin in the maxillary sinus to prevent recurrence. There are several surgical options for ACP removal, which include simple polypectomy, endoscopic assisted middle meatal antrostomy (MMA), Caldwell-Luc approach and combined endoscopic MMA and transcanine surgery. Endoscopic surgery is a challenge in paediatrics due to the limited space for surgery in a narrow nasal cavity. Caldwell-Luc approach provides easier pathway for surgery; however, it may cause injury to the growth plate or ossifying centres and deciduous teeth. Ozdek et al. recorded recurrence rates of up to $22 \%$ after middle meatal antrostomy alone, but no recurrence after combining MMA with transcanine surgery ${ }^{(10)}$. As for our patient, the ACP was removed via endoscopic MMA, which has a favourable outcome on 2 years of follow-up.

\section{CONCLUSION}

Antrochoanal polyp is common in children and young adults; however, intranasal proliferative fasciitis is extremely rare and has not been reported thus far. There could be a variation in presentation as seen in our patient, which did not follow the norm from the duration of presenting symptoms and clinical appearance. Therefore, ACP should always be considered as a differential diagnosis for a nasopharyngeal mass in children; however, the diagnosis of PF could only be made histopathologically. The mainstay of treatment is to ensure complete removal of the polyp and its origin to prevent recurrence.

\section{Conflict of interest}

The authors do not declare any financial or personal links with other persons or organisations that might adversely affect the content of the publication or claim any right to the publication.

\section{References}

1. Gendeh BS, Long YT, Misiran K: Antrochoanal polyps: clinical presentation and the role of powered endoscopic polypectomy. Asian J Surg 2004; 27: 22-25.

2. Sabino HAC, Faria FM, Tamashiro E et al.: Bilateral antrochoanal polyp: case report. Braz J Otorhinolaryngol 2014; 80: 182-183.

3. Meis JM, Enzinger FM: Proliferative fasciitis and myositis of childhood. Am J Surg Pathol 1992; 16: 364-372.

4. Goldblum JR, Folpe AL, Weiss SW: Benign fibroblastic/myofibroblastic proliferations, including superficial fibromatoses. In: Goldblum JR, Folpe AL, Weiss SW: Enzinger and Weiss's Soft Tissue Tumors. $6^{\text {th }}$ ed., Elsevier, Philadelphia 2014: 204.

5. Forcucci JA, Bruner ET, Smith MT: Benign soft tissue lesions that may mimic malignancy. Semin Diagn Pathol 2016; 33: 50-59.

6. Eladl HM, Elmorsy SM: Endoscopic surgery in pediatric recurrent antrochoanal polyp, rule of wide ostium. Int J Pediatr Otorhinolaryngol 2011; 75: 1372-1375.

7. Woolley AL, Clary RA, Lusk RP: Antrochoanal polyps in children. Am J Otolaryngol 1996; 17: 368-373.

8. de Freitas MR, Giesta RP, Pinheiro SD et al.: Antrochoanal polyp: a review of sixteen cases. Braz J Otorhinolaryngol 2006; 72: 831-835.

9. Weissman JL, Tabor EK, Curtin HD: Sphenochoanal polyps: evaluation with CT and MR imaging. Radiology 1991; 178: 145-148.

10. Ozdek A, Samim E, Bayiz U et al.: Antrochoanal polyps in children. Int J Pediatr Otorhinolaryngol 2002; 65: 213-218. 